\title{
PENGEMBANGAN MEDIA PEMBELAJARAN INTERAKTIF SENI MUSIK UNTUK SISWA SMP
}

\author{
Panca Putri Rusdewanti, Abdul Gafur \\ Fakultas Bahasa dan Seni UNY, Fakultas Ilmu Sosiak UNY \\ panca_putri@yahoo.com, abdul_gafur@uny.ac.id
}

\begin{abstract}
Abstrak
Penelitian ini bertujuan untuk Menghasilkan produk software multimedia pembelajaran yang layak untuk mendukung pembelajaran seni musik. Jenis penelitian ini adalah penelitian pengembangan (Research and Development). Pelaksanaan penelitian meliputi empat tahap yaitu: studi pendahuluan, perencanaan, desain, dan pengembangan. Teknik sampling yang digunakan adalah purposive sampling. Teknik analisis data meliputi analisis secara kualitatif dan kuantitatif. Data kualitatif berupa kritik, saran, dan masukan dari ahli materi, ahli media, dan siswa yang dihimpun untuk memperbaiki produk yang dikembangkan. Data kuantitatif berupa data ordinal dianalisis menggunakan modus. Produk yang dihasilkan berupa CD pembelajaran interaktif yang terdiri dari kompetensi, materi, evaluasi, dan referensi. Hasil penelitian menunjukkan hasil sebagai berikut. (1) Ahli materi menilai aspek pembelajaran dan aspek materi dengan kategori sangat baik. (2) Ahli media menilai aspek media dengan kategori baik. (3) Hasil uji coba lapangan menunjukkan bahwa aspek pembelajaran masuk kategori baik (skala 4 sebanyak 158 atau 47,45\%), aspek materi masuk kategori baik (skala 4 sebanyak 113 atau 50,90\%), dan aspek media masuk kategri sangat baik (skala 5 sebanyak 161 atau 48,35\%). Hasil penilaian ini menunjukkan bahwa software multimedia pembelajaran interaktif seni musik layak digunakan siswa SMP.
\end{abstract}

Kata kunci: pengembangan, multimedia, pembelajaran seni musik

\section{DEVELOPING AN INTERACTIVE MUSICAL LEARNING MULTIMEDIA FOR JUNIOR HIGH SCHOOL STUDENTS}

\author{
Panca Putri Rusdewanti, Abdul Gafur \\ Fakultas Bahasa dan Seni UNY, Fakultas Ilmu Sosiak UNY \\ panca_putri@yahoo.com, abdul_gafur@uny.ac.id
}

\begin{abstract}
This research aims to: (1) Produce multimedia software that can support musical learning; (2) Know the software's compatibility as a learning material. This is a Research and Development model of research. It was done in four phases: prelemenary study, planning, design, and development. The sampling method used here is purposive sampling. Data analysis methods include qualitative and quantitative analyses. Qualitative data is comprised of critics, suggestions, and inputs from the subject experts, media experts, and students for improving the final products. Quantitative data is ordinal data analyzed using modus. The results of this research show that: (1) Subject experts put the learning and subject aspects in a very good category; (2) Media experts put the media aspect in a good category; (3) Field test result indicates that the learning aspect is in good category (scale 4; 158 or $47.45 \%$ ), subject aspect is in good category (scale $4 ; 113$ or $50.90 \%$ ), and media aspect is in very good category (scale 5; 161 or $48.35 \%$ ). Results suggest that multimedia softwares which provide interactive musical learning are considered good as a learning material for junior high school students.
\end{abstract}

Keywords: development, multimedia, learning of music education 


\section{Pendahuluan}

Pelajaran Seni Budaya diberikan di sekolah karena keunikan, kebermaknaan, dan kebermanfaatan terhadap kebutuhan perkembangan siswa. Pemberian pengalaman estetik dalam bentuk kegiatan berekspresi/kreasi melalui pendekatan belajar seni tidak dapat diberikan oleh mata pelajaran lain. Dalam pembelajaran seni budaya aspek seni budaya tidak dibahas secara tersendiri tetapi terintegrasi dengan seni. Karena itu mata pelajaran Seni Budaya pada dasarnya merupakan pendidikan seni yang berbasis budaya. (Permen no. 23, 2006, p.590).

Pelajaran Seni Budaya sebagai mata pelajaran diajarkan pada jenjang pendidikan dasar dan menengah. Pada jenjang prasekolah atau Taman Kanak-kanak (TK), pelaksanaan pendidikan seni dan budaya berorientasi pada belajar dan bermain. Tujuannya adalah mengaktifkan segala kemampuan dan potensi dasar yang dimiliki anak, dengan penekanan pada aspek psikomotorik. Sedangkan di Sekolah Dasar (SD), mata pelajaran tersebut diajarkan sebagai bahan pengetahuan awal melalui pengenalan unsur-unsur harmoni, irama, dan keseimbangan dengan penekanan pada aspek sikap (afektif). Kemudian di Sekolah Menengah Pertama (SMP), pelaksanaan pendidikan seni dan budaya berorientasi pada aspek kognitif dengan memasukkan unsur ide, gagasan, dan tema pada pembelajarannya.

Berdasarkan kurikulum, fungsi dan tujuan pendidikan seni budaya di Sekolah Menengah Pertama dirancang agar dapat mengembangkan sikap, kemampuan dan keterampilan dasar, kreativitas, kepekaan cita rasa keindahan, serta berkembangnya apresiasi siswa. Ruang lingkup bahan ajarnya meliputi seni rupa, seni musik, seni tari dan seni teater. Pada intinya, pendidikan seni budaya di Sekolah Menengah Pertama, tidak dimaksudkan untuk membentuk atau mencipta seniman, tetapi justru menempatkan seni sebagai alat pendidikan.

Seni musik sebagai bagian dari mata pelajaran seni budaya sebetulnya sangat disukai oleh siswa. Mereka beranggapan yang akan dipelajari bersifat pratek. Pada kenyataannya mata pelajaran tersebut $40 \%$ bersifat praktek dan $60 \%$ bersifat teoritis. Sehingga siswa kurang aktif dalam proses pembelajaran. Sebetulnya pada pelajaran tersebut guru bisa menjelaskan sekaligus mempraktekkan atau memberi contoh apa yang dipelajari. Akan tetapi ada beberapa kendala yang dihadapi oleh sekolah, antara lain tidak adanya alat musik yang mendukung, tidak adanya ruangan khusus untuk belajar musik sehingga terkadang mengganggu kelas disebelahnya apabila materi pelajaran bersifat praktek, faktor guru yang terkadang kurang terampil dalam memainkan alat musik sehingga tidak bisa memberikan contoh kepada siswa, dan belum adanya media pembelajaran yang mendukung pembelajaran seni musik di sekolah.

Berdasarkan observasi di lapangan dijumpai berbagai indikasi masalah berkaitan dengan pelaksanaan pendidikan seni antara lain: padatnya kurikulum, sehingga tatap muka mata pelajaran seni sangat terbatas, pembelajaran seni musik yang kurang menarik, masih banyaknya guru yang tidak berlatar belakang pendidikan seni mengajar mata pelajaran seni, kurangnya sarana dan prasarana yang memadai, serta minimnya alat dan media pembelajaran. Walaupun banyak guru yang menyadari pentingnya media sebagai alat untuk menyampaikan pesan-pesan pembelajaran, belum banyak guru yang memanfaatkan media yang ada disekitarnya karena persiapan mengajar menjadi lebih lama.

Permasalahan yang dihadapi sekolah dalam pemanfaatan media saat ini adalah kurang tersedianya media pembelajaran interaktif mata pelajaran seni budaya di sekolah. Masih banyaknya guru yang belum mampu membuat media pembelajaran interaktif. Keterbatasan ini tentunya cukup menyulitkan guru untuk memanfaatkan komputer yang ada disekolah. Padahal umumnya siswa telah memiliki keterampilan dasar menggunakan komputer karena telah mendapatkan pembelajaran teknologi informasi. Sehingga laboratorium 
komputer sekolah yang cukup memadai kurang dimanfaatkan secara optimal.

Diperlukan media pembelajaran berupa produk multimedia pembelajaran Seni Budaya yang dapat meningkatkan minat dan motivasi belajar siswa, memfokuskan perhatian siswa, menjadikan siswa aktif dalam proses pembelajaran dan menciptakan suasana belajar yang menyenangkan bagi siswa sehingga pembelajaran dapat berlangsung secara efektif, efisien, dan menarik untuk membantu siswa dalam mencapai kompetensi dasar yang telah ditetapkan.

Pesatnya kemajuan teknologi komputer membawa dampak pada meningkatnya jumlah perangkat keras komputer di pasaran dengan harga yang semakin murah. Jumlah kepemilikan komputer baik oleh lembaga pendidikan maupun oleh pendidikpun meningkat. Konsekuensinya adalah perlu dipikirkan pemanfaatan komputer tersebut untuk keperluan peningkatan poses belajar mengajar.

Salah satu aspek yang jelas dan tampak dalam pembelajaran adalah dipergunakannya teknologi dalam merekayasa suatu program pembelajaran. Kegiatan ini merupakan suatu langkah yang harus dilakukan oleh setiap pendidik dalam proses pembelajaran. Penggunaan media pembelajaran baik berupa modul cetak, modul interaktif, ataupun e-learning dimaksudkan untuk membantu terjadinya proses pembelajaran yang lebih efektif dan efisien.

Pada hakikatnya proses pembelajaran adalah proses komunikasi. Proses komunikasi (proses penyampaian pesan) harus diciptakan atau diwujudkan melalui kegiatan penyampaian dan tukar menukar pesan atau informasi oleh guru. Pesan atau informasi dapat berupa pengetahuan, keahlian, keterampilan, ide, pengalaman, dan sebagainya. Melalui proses komunikasi, pesan atau informasi dapat diserap dan dihayati orang lain.

Salah satu peranan teknologi dalam proses pembelajaran saat ini adalah semakin berkembangnya produk-produk media pembelajaran yang menggunakan komputer sebagai basis pengembangannya, baik berupa modul maupun program pembelajaran lewat web pembelajaran yang dikenal dengan istilah e-learning atau web based instruction. Yang perlu mendapat perhatian yakni jangan sampai siswa terasing terhadap media khususnya media yang interaktif. Pembelajaran berbantuan komputer (PBK) memiliki lima keunggulan (Simonson \& Thomson, 1994), yaitu: (1) PBK efektif dalam memperbaiki penguasaan pebelajar dalam semua jenjang pendidikan; (2) PBK sangat efektif dalam memperbaiki penguasaan pembelajaran pada tingkat sekolah dasar, yang berlanjut pada tingkat menegah sampai ke perguruan tinggi; (3) PBK memberikan efek yang positif pada sikap pebelajar terhadap materi pelajaran, pembelajaran, dan terhadap teknologi komputer; (4) PBK dapat menghemat waktu untuk pembelajaran; (5) temuan riset dari berbagai studi dengan metode yang berbeda serta setting pebelajar yang berbeda terhadap konsistensi secara meyakinkan.

Manfaat penggunaan multimedia dijelaskan Lee (Ouda Teda Uda, 2005, p.3) bahwa paling sedikit ada delapan alasan pemakaian komputer sebagai media pembelajaran, yaitu pengalaman, motivasi, meningkatkan pembelajaran, materi yang otentik, interaksi yang lebih luas, lebih pribadi, tidak terpaku pada sumber tunggal, dan pemahaman global. Philip (1997, p.12) menyatakan bahwa "IMM has the potensial to accommodate people with different learning style". Artinya, multimedia interaktif dapat memiliki potensi untuk menciptakan suatu lingkungan multisensori yang mendukung cara belajar tertentu.

Diharapkan media pembelajaran interaktif dapat meningkatkan minat dan motivasi belajar siswa, memfokuskan perhatian siswa, memungkinkan siswa belajar secara mandiri, menjadikan siswa aktif dalam proses pembelajaran dan menciptakan suasana belajar yang menyenangkan sehingga pembelajaran dapat berlangsung secara efektif, efisien, dan menarik untuk membantu siswa dalam mencapai kompetensi dasar yang telah ditetapkan. 
Sesuai dengan rumusan masalah di atas, maka tujuan penelitian pengembangan ini adalah menghasilkan produk multimedia pembelajaran yang layak untuk mendukung pembelajaran seni musik. Smaldino, Russel, Mollenda, et al. (2005, p.141) menjelaskan "Multimedia involves more than simply integrating these formats into a structured program in which each element complements the others so that tnghe whole is greater than the sum of the parts". Multimedia adalah media yang menggabungkan dua unsur atau lebih media (teks, grafis, gambar, foto, audio, video dan animasi) secara terintegrasi. Pendapat lain diungkapkan oleh Phillips (1997, p.8) bahwa komponen multimedia ditandai dengan adanya teks, gambar, suara, animasi dan video; beberapa atau semuanya diatur dalam program yang berkesinambungan.

Multimedia interaktif menurut Schwier \& Misanchuk (1993, p.6) adalah "program pembelajaran yang terdiri atas berbagai sumber belajar dengan pengoperasian menggunakan komputer". Program sengaja didesain dan dilihat respon kelayakan apakah (misalnya menu, masalah, simulasi, pertanyaan) berpengaruh pada sekuensi, ukuran, konteks dan bentuk program.

Karakteristik multimedia pembelajaran menurut Ariasdi (2008, p.3) sebagai berikut: (1) memiliki lebih dari satu media yang konvergen, misalnya menggabungkan unsur audio dan visual; (2) bersifat interaktif, dalam pengertian memiliki kemampuan untuk mengakomodasi respon pengguna; dan (3) bersifat mandiri, dalam pengertian memberi kemudahan dan kelengkapan isi sedemikian rupa sehingga pengguna bisa menggunakan tanpa bimbingan orang lain.

Pemanfaatan media pembelajaran secara tepat dan bervariasi dapat mengatasi sikap pasif siswa, dengan kata lain media yang sesuai kebutuhan akan mengoptimalkan perolehan hasil belajar siswa. Multimedia fleksibel dalam menyesuaikan kecepatan belajar siswa. Siswa yang memiliki kecepatan belajar lebih tinggi dapat lebih cepat menyelesaikan kegiatan belajar- nya, sedangkan siswa dengan kecepatan belajar lambat dapat menyelesaikan aktivitas belajarnya sesuai dengan kecepatannya masing-masing. Hal ini sangat berbeda dengan pembelajaran di kelas konvensional, di mana setiap siswa dipaksa belajar dengan kecepatan yang ditentukan oleh guru. Siswa yang mempunyai kecepatan belajar tinggi dapat merasa bosan, sebaliknya siswa dengan kecepatan belajar rendah merasa pembelajaran terlalu cepat untuk diikuti.

Nana Sudjana dan Ahmad Rivai (2007, p.2) menyatakan bahwa multimedia bermanfaat dalam proses pembelajaran, maka menjadikan: (1) pengajaran lebih menarik perhatian siswa sehingga dapat menimbulkan motivasi belajar; (2) bahan pengajaran lebih jelas maknanya sehingga dapat dipahami oleh siswa dan memungkinkan siswa menguasai tujuan pembelajaran dengan baik; (3) metode mengajar lebih bervariasi; (4) siswa lebih banyak melakukan kegiatan belajar, sebab tidak hanya mendengarkan penjelasan guru tetapi ikut terlibat dalam aktifitas lain seperti mengamati, melakukan, mendemonstrasikan dan lain-lain.

Musik merupakan salah satu kontribusi seni yang paling penting dalam sejarah perkembangan manusia dan merupakan multi-disiplin ilmu yang melibatkan seluruh koordinasi fisik-mental manusia. Pembelajaran musik sejak dini dapat meningkatkan kemampuan fundamental belajar di berbagai bidang, seperti mengasah berbagai kemampuan intelegensi/kecerdasan (multiple intelligence), kecerdasan intelektual (IQ) dan kecerdasan emosional $(E Q)$, mengaktifkan kinerja otak kanan dan kiri dan meningkatkan kemampuan berfikir (daya ingat dan konsentrasi) seseorang, melatih kemampuan berfikir secara abstrak, kemampuan belajar secara kognitif (cognitive learning and reasoning), meningkatkan kemampuan berbahasa asing dan membaca (language), serta melatih kemampuan otot motorik halus anak (fine motor skills).

Dewasa ini telah banyak penelitian yang dilakukan mengenai besarnya manfa- 
at dan pengaruh musik pada anak-anak. Salah satunya seperti diungkapkan pada pernyataan berikut, " ..... that musical training for children increases scholastic achievement and improves overall behavior and attitude." (Chicago Center School of Music). Salah satu manfaat belajar musik adalah dapat memberikan pengaruh bagi pertumbuhan seorang anak. Hal senada dikatakan oleh Lois Choksy "Music is a valuable activity that contribute immensely to the development of a child" (2004, p.1).

Dalam kegiatan pembelajaran musik melalui pengalaman musik ada 6 jenis, yaitu: (1) bernyanyi, (2) mendengar musik, (3) bergerak mengikuti musik, (4) bermain musik, (5) membaca musik, (6) kreativitas musik. Kegiatan-kegiatan di atas tampak bahwa yang diutamakan pada pembelajaran musik adalah mengaktifkan seluruh indra, akal, dan perasaan anak untuk mengalami musik melalui kegiatan berolah musik. Di sini, guru dituntut untuk memiliki pengetahuan, ketrampilan musik di samping ketrampilan mengajar musik.

Usia siswa SMP termasuk usia remaja yang mempunyai karakteristik sendiri. Kanopka (Yusuf, 2009, p.9) menyatakan bahwa masa remaja adalah segmen kehidupan yang penting dalam siklus perkembangan siswa dan merupakan masa transisi (dari masa anak-anak ke masa dewasa) yang diarahkan kepada perkembangan masa dewasa yang sehat. Kemampuan berfikir para remaja berkembang sedemikian rupa sehingga mereka dengan mudah membayangkan banyak alternatif pemecahan masalah beserta kemungkinan akibat atau hasilnya. Kapasitas berfikir secara logis dan abstrak mereka berkembang sehingga mereka mampu berfikir multidimensi seperti ilmuwan.

Para remaja tidak lagi menerima informasi apa adanya, tetapi mereka akan memproses informasi itu serta mengadaptasikannya dengan pemikiran mereka sendiri. Mereka juga mampu mengintegrasikan pengalaman masa lalu dan sekarang untuk ditranformasikan menjadi konklusi, prediksi, dan rencana untuk masa depan.
Dalam penelitian ini penulis mengkaji bidang seni musik kelas VIII dengan standart kompetensi yang ingin dicapai adalah sebagai berikut: mengapresiasi karya seni musik dengan kompetensi dasar, mengidentifikasi jenis karya seni musik daerah nusantara dan menampilkan sikap apresiatif terhadap keunikan gagasan dan teknik karya seni musik daerah nusantara.

\section{Metode Penelitian}

Penelitian ini adalah penelitian pengembangan (Research and Development) yang berorientasi pada pengembangan produk multimedia pembelajaran. Di dalam metode penelitian ini akan dibahas secara berurutan model pengembangan yang meliputi tahapan studi pendahuluan, perencanaan, desain dan pengembangan, uji coba produk, serta uji coba produk yang meliputi desain uji coba, subjek uji coba, jenis data, instrumen pengumpulan data, dan teknik analisis data.

Model pengembangan dalam penelitian ini mengadaptasi model pengembangan Borg \& Gall (1983), model pengembangan Lee \& Owens (2004), dan model pengembangan Allesi \& Trolip (2001). Tahapan-tahapan dalam penelitian pengembangan ini secara garis besar meliputi tahap studi pendahuluan, tahap perencanaan, tahap desain, dan tahap pengembangan.

Model pengembangan yang diadaptasi dari Borg \& Gall (1983) yaitu tahap studi pendahuluan sebagai analisis kebutuhan atas permasalahan-permasalahan yang timbul pada proses pembelajaran Seni Budaya. Berawal dari permasalahan tersebut selanjutnya ditemukan solusi yang dapat memecahkan permasalahan yang terkait dengan pembelajaran. Model pengembangan yang diadaptasi dari model Lee \& Owen (2004) adalah tahap perencanaan. Alasan mengadaptasi bagian tersebut karena tahap-tahap perencanaan lebih detail, dan sudah memuat tahap-tahap desain pembelajaran.

Model pengembangan menurut Allesi \& Trollip (2001) bagian yang di- 
adaptasi adalah desain dan pengembangan. Alasan mengadaptasi bagian tersebut adalah pada bagian desain yang memiliki alur kerja lebih terarah pada aktivitas pengaturan, penyusunan isi dan pembuatan produk multimedia pembelajaran. Berikut ini garis besar keempat tahapan penelitian pengembangan:

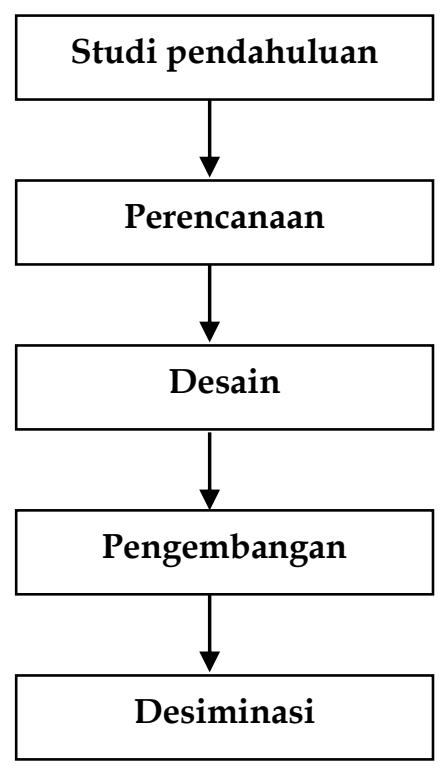

Gambar 1. Garis Besar Tahap Penelitian dan Pengembangan

Produk multimedia pembelajaran interaktif yang dikemas dalam bentuk CD pembelajaran sebelum dimanfaatkan secara umum perlu diuji coba terlebih dahulu untuk mendapatkan masukan baik dari aspek media maupun aspek materi pembelajaran. Dalam melakukan uji coba, diharapkan produk yang dihasilkan teruji secara teoritis dan empiris. Data-data yang diperoleh dari uji coba akan digunakan untuk memperbaiki dan menyempurnakan produk pembelajaran

Uji coba produk dilakukan untuk mendapatkan umpan balik secara langsung dari pengguna, serta untuk mengetahui kelemahan dan kekurangan produk yang dikembangkan sebagai dasar untuk melakukan revisi. Secara rinci desain uji coba meliputi: (1) uji alpha berupa validasi produk oleh ahli materi dan ahli media berkaitan dengan produk menjadi acuan untuk perbaikan dan revisi produk; (2) uji beta untuk mengetahui tanggapan, saran, dan masukan dari guru terhadap produk yang dikembangkan. Tanggapan, saran, dan masukan tersebut kemudian disusun dan dianalisis untuk revisi akhir produk. Uji beta dilakukan oleh siswa kelas VIII sebanyak 6 orang secara acak; (3) revisi produk dilakukan sesuai dengan saran, masukan, tanggapan dari ahli materi, ahli media, dan guru mata pelajaran (uji alpha dan uji beta).

Penelitian pengembangan ini melibatkan partisipasi siswa kelas 8 SMP Muhammadiyah 2 Yogyakarta berjumlah 37 orang. Berdasarkan tujuan uji coba yaitu untuk mengetahui kualitas dan kelayakan produk yang dibuat, maka teknik sampling yang digunakan adalah purposive sampling. Purposive sampling adalah pengambilan sampel sumber data dengan pertimbangan tertentu, dan sampel-sampel yang dipilih diharapkan dapat memberikan informasi maksimal (Sugiyono, 2005, p.54).

Uji coba produk dimaksudkan untuk mengumpulkan data yang dapat digunakan sebagai dasar untuk mengetahui kualitas dari masing-masing komponen pengembangan multimedia pembelajaran agar nantinya dapat digunakan dalam proses pembelajaran. Data yang diperoleh dari hasil uji coba ini ada dua yaitu data kuantitatif dan data kualitatif. Data kuantitatif untuk selanjutnya di konversi ke dalam data kualitatif.

Data kuantitatif berbentuk data ordinal diperoleh dari hasil penilaian expert judgement yaitu dosen seni musik sebagai ahli materi, ahli multimedia dan hasil uji lapangan. Data kualitatif berbentuk uraian merupakan hasil observasi, hasil wawancara, saran dan masukan dari responden uji coba dan pengamatan. Data-data tersebut dibutuhkan agar nantinya dapat memberikan gambaran mengenai kualitas materi dan tampilan produk multimedia pembelajaran.

Instrumen yang digunakan untuk mengumpulkan data dalam penelitian ini adalah angket, pedoman wawancara, dan pengamatan. Kisi-kisi instrumen yang digunakan pada penelitian ini merupakan adaptasi dari Ade Koesnandar (2004, p.14). 
Angket yang disusun meliputi tiga jenis sesuai dengan peran dan posisi responden dalam penelitian pengembangan ini, yaitu: Angket untuk ahli materi, penyusunan angket ditinjau dari aspek kualitas matetri pembelajaran dan strategi pembelajaran.. Tujuan dari penyusunan angket ini adalah untuk memperoleh data tentang kualitas desain pembelajaran. Angket untuk ahli media, digunakan untuk memperoleh data tentang kualitas teknis dari produk yang dihasilkan, diisi oleh seseorang yang mempunyai keahlian dalam bidang multimedia. Angket untuk siswa sebagai subjek uji coba/responden. Angket ini digunakan untuk memperoleh data tentang kualitas CD pembelajaran ditinjau dari sudut pandang siswa pada saat uji coba lapangan terhadap aspek materi, aspek pembelajaran dan aspek media.

Data yang diperoleh dalam penelitian ini diklarifikasi menjadi dua, yaitu data kualitatif dan data kuantitatif. Data kualitatif berupa kritik, saran, dan masukan dari ahli materi, ahli media, dan siswa yang dihimpun serta disarikan untuk memperbaiki produk yang dikembangkan. Data kuantitatif berupa data ordinal yang diperoleh dari ahli materi, ahli media, dan siswa yang menggunakan skala Likert dianalis menggunakan modus. Seperti yang dikemukakan oleh Mogey (1998: 21):

The data collected are ordinal: they have an inherent order or sequence, but one cannot assume that the respondent means that the difference between agreeing and strongly agreeing is the same as between agreeing and being undecided. Descriptive Techniques: (1) Summarise using a median or mode (not a mean), the mode is probably the most suitable for easy interpretasion; (2) Express variability in terms of the range or inter quartile range (not the standart deviation); (3) Display the distribution of observations in a dotplot or a barchart (it can.t be a histogram, because the data is not continuous).

Bila data yang dikumpulkan adalah ordinal, maka data memiliki perintah yang melekat atau berurutan, tetapi responden tidak dapat mengasumsikan bahwa perbedaan pendapat orang diantara setuju dan sangat setuju berarti sama antara setuju dan yang ragu-ragu. Teknik deskriptifnya adalah: (1) meringkas menggunakan median atau modus; (2) express variabilitas dalam rentang atau antar kuartil rentang (bukan standar deviasi); (3) Tampilan distribusi pengamatan di dotlpot atau barchart (tidak dapat menjadi histogram, sebab data tidak kontinu).

Teknik deskiptif ini digunakan dengan alasan karena instrumen yang digunakan adalah skala Likert, sehingga dalam upaya penyimpulannya harus memakai modus, bukan rata-rata (mean). Data yang dikumpulkan dengan menggunakan skala Likert adalah data ordinal sehingga sifatnya adalah urutan yang tidak dapat dipisahkan, tetapi tidak dapat diasumsikan bahwa makna setuju dengan benar-benar setuju adalah sama. Penyajian data menggunakan dotplot atau barchart karena datanya adalah urutan. Penilaian setiap aspek pada produk yang dikembangkan dalam penelitian ini dengan menggunakan skala Likert, dikatakan layak jika modus dari responden adalah minimal 4 (bagus).

\section{Hasil Penelitian dan Pembahasan}

Multimedia pembelajaran interaktif Seni Musik untuk peserta didik SMP dikembangkan berdasar pada analisis kebutuhan yang disimpulkan setelah mendapatkan berbagai informasi diantaranya kondisi pembelajaran mata pelajaran Seni Musik dan kompetensi dasar yang sangat membutuhkan multimedia pembelajaran interaktif. Pengumpulan informasi dilakukan melalui studi pustaka dan studi lapangan. Studi lapangan dilakukan melalui pengamatan terbatas pada SMP Muhammadiyah 2 Yogyakarta. Di samping itu, peneliti juga menyebarkan angket analisis kebutuhan, yang bertujuan untuk menjaring informasi mengenai penggunaan jenis sumber belajar, proses pembelajaran, penggunaan CAI dalam proses pembelajaran dan pengembangan multimedia pem- 
belajaran yang dibutuhkan oleh peserta didik. Data yang diperoleh dari kegiatan pengumpulan informasi ini adalah kajian pustaka, pengamatan, dan kuesioner.

Kegiatan studi pustaka meliputi studi kurikulum, silabus mata pelajaran Seni Musik, buku-buku pelajaran Seni Musik dan penggunaan komputer dalam pembelajaran Seni Musik. Melalui kegiatan ini diperoleh data sebagai berikut: (1) silabus mata pelajaran Seni Musik, khususnya pada kompetensi dasar yaitu mendeskripsikan Musik Nusantara beserta unsurunsur pendukungnya. Diketahui bahwa peserta didik mengalami kesulitan untuk menguasai keterampilan tersebut. Hal ini disebabkan terbatasnya sumber belajar yang mereka temui. Sehingga, multimedia pembelajaran Seni Musik sangat dibutuhkan oleh peserta didik; (2) penggunaan multimedia pembelajaran interaktif sebagai sumber belajar selain buku pelajaran memberikan dampak yang sangat baik terhadap proses dan hasil pembelajaran. Di samping itu, penggunaan komputer dalam pembelajaran Seni Musik dapat dioptimalkan.

Hasil observasi/pengamatan terbatas terhadap proses pembelajaran Seni Musik di SMP Muhammadiyah 2 Yogyakarta, diperoleh data atau gambaran proses pembelajaran. Pada pembelajaran Seni Musik yaitu peserta didik kurang antusias dalam mengikuti proses pembelajaran khususnya pembelajaran Musik Nusantara yang dilakukan oleh guru di sekolah tersebut karena strategi pembelajaran yang diterapkan cenderung menggunakan pendekatan tradisional atau ekspositori, teacher centered learning, guru tidak pernah menggunakan multimedia pembelajaran interaktif.

Di samping melakukan observasi/ pengamatan terbatas terhadap proses pembelajaran Seni Musik di SMP Muhammadiyah 2 Yogyakarta, peneliti juga menyebarkan kuesioner analisis kebutuhan mengenai jenis sumber belajar yang digunakan dalam pembelajaran Seni Musik, penggunaan CAI dan pengembangan multimedia pembelajaran Seni Musik. Kuesioner analisis kebutuhan ini digunakan peneliti untuk menjaring informasi mengenai sumber belajar (CAI) yang dibutuhkan oleh peserta didik dalam proses pembelajaran Seni Musik. Berdasarkan hasil kuesioner tersebut digunakan sebagai landasan dalam mengembangkan multimedia pembelajaran. Di sisi lain, sekolah telah mempunyai fasilitas belajar yang cukup memadai diantaranya laboratorium komputer yang belum digunakan dan dimanfaatkan secara optimal untuk pembelajaran, laboratorium komputer hanya digunakan untuk pembelajaran TIK.

Pengembangan produk multimedia pembelajaran pada tesis ini menggunakan pengembangan produk dari Macromedia. Target pengguna produk multimedia pembelajaran interaktif ini yaitu siswa SMP. Produk multimedia pembelajaran ini dikemas dalam bentuk Compact Disc (CD) interaktif yang dapat dijalankan pada komputer. Proses produksi multimedia interaktif ini diolah dalam program Macromedia flash 8 dan program-program pendukung lainnya seperti Coreldraw, Adobe Photoshop CS2, Adobe Audition, dan swish mx. Proses produksi tersebut dapat berjalan dengan lancar, cepat, dan lebih tertata karena didasarkan pada rancangan flowchart dan storyboard yang sudah dibuat sebelumnya dan kesiapan bahan-bahan yang diperlukan sesuai dengan karakteristik pengguna.

\section{Pembuatan naskah}

Berdasarkan silabus, dibuat flowchart yaitu diagram alur dalam pembuatan multimedia pembelajaran interaktif Langkah selanjutnya adalah pembuatan storyboard untuk menggambarkan bentuk tampilan setiap frame dalam multimedia pembelajaran yang dikembangkan. Pengumpulan semua materi yang dibutuhkan dalam pembuatan multimedia pembelajaran. Langkah selanjutnya adalah pengumpulan bahan-bahan pendukung seperti foto, video, audio, animasi, image dan lainlain.

\section{Pembuatan produk}

Berdasarkan storyboard dan flowchart, selanjutnya semua bahan diolah di 
dalam komputer menggunakan program Macromedia flash 8. Setelah produk awal selesai dikembangkan, maka terlebih dahulu dilakukan pengetesan sebelum produk awal divalidasi oleh expert judgement dan diuji coba kepada siswa. Pengetesan dilakukan secara internal yaitu pengetesan jalannya program secara keseluruhan, dan secara eksternal yaitu pengetesan ke beberapa jenis komputer dari yang setara dengan Pentium III.

Secara garis besar produk multimedia hasil pengembangan tahap awal berisi pendahuluan, materi, dan evaluasi. Pendahuluan, yang berisi rumusan standar kompetensi, kompetensi dasar, indikator pencapaian dan peta konsep. Materi yang berisi pengertian musik nusantara, unsurunsur musik, fungsi musik, jenis musik, bentuk instrumen dan keunikan musik. Evaluasi, untuk mengetahui tingkat kompetensi siswa yang telah dimilikinya berupa tes. Siswa harus menyelesaikan seluruh tes, agar dapat melihat skor hasil tes tersebut.

Bahan penarik perhatian, berupa flowchart dan storyboard perpaduan antara animasi, teks, gambar, foto, warna, tampilan layar, grafis, animasi, suara, musik dan video dengan tombol-tombol navigasi interaktif untuk membuat pembelajaran menjadi lebih interaktif dan menarik.

Setelah produk multimedia interaktif hasil pengembangan dalam bentuk CD interaktif tersebut selesai, selanjutnya dilakukan pengetesan baik internal maupun eksternal. Hasilnya, produk tersebut dapat berjalan dengan lancar baik secara internal maupun eksternal. Dilanjutkan pada tahap "evaluasi" produk yaitu validasi ahli media dan ahli materi, kemudian dilanjutkan pada tahap uji coba, yaitu uji coba kepada siswa dengan desain uji coba kelompok kecil, uji coba kelompok besar dan uji coba lapangan. Melalui serangkaian validasi ahli dan uji coba kepada siswa, selanjutnya produk akhir multimedia pembelajaran interaktif dihasilkan dengan memasukkan saran dan revisi dari ahli media instruksional dan ahli materi serta siswa.

\section{Analisis Data Validasi Ahli Materi}

Hasil penilaian ahli materi tentang aspek pembelajaran diketahui skor penilaian ahli materi dengan skala 4 sebanyak 7 dan skala 5 sebanyak 9. Dengan demikian kategori Baik 43,75\% dan kategori Sangat Baik 56,25\%. Bila dilihat dari modus aspek kualitas materi dikategorikan Sangat Baik.

Hasil penilaian ahli materi tentang aspek materi diketahui skor penilaian ahli materi dengan skala skala 4 sebanyak 2 dan skala 5 sebanyak 6 . Dengan demikian kategori kategori Baik 25\% dan kategori Sangat Baik 75\%. Bila dilihat dari modus aspek kualitas materi dikategorikan Sangat Baik. Berdasarkan hasil penilaian ahli materi, dapat disimpulkan bahwa aspek pembelajaran dan aspek materi layak untuk diuji cobakan.

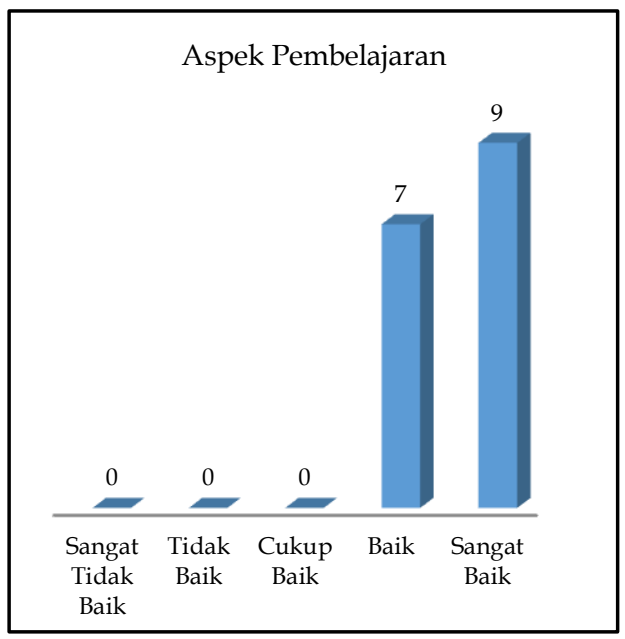

Gambar 2. Perolehan Skor Penilaian Aspek Pembelajaran oleh Ahli Materi

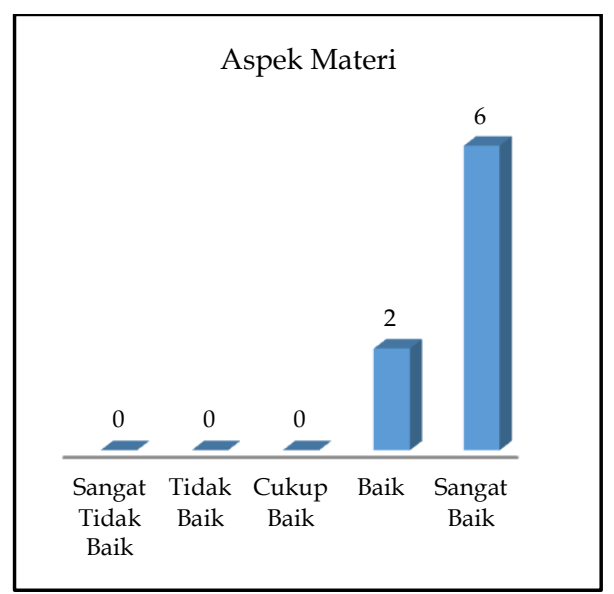

Gambar 3. Perolehan Skor Penilaian Aspek Materi oleh Ahli Materi 


\section{Analisis Data Validasi Ahli Media}

Penilaian ahli media tentang aspek media diketahui skor penilaian ahli media dengan skala 3 sebanyak 1 , skala 4 sebanyak 5 dan skala 5 sebanyak 11 . Dengan demikian kategori Cukup Baik 5,88\%, kategori Baik 29,41\% dan kategori Sangat Baik $64,71 \%$. Bila dilihat dari modus aspek kualitas media dikategorikan Sangat Baik.

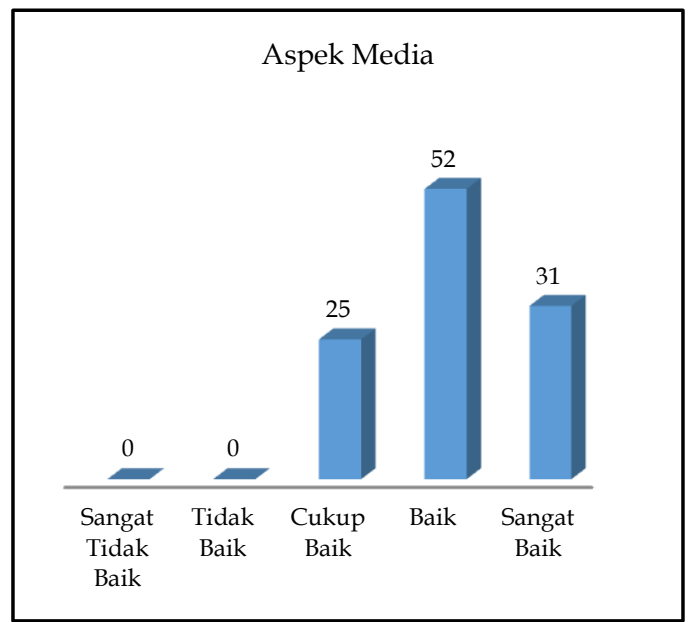

Gambar 4. Perolehan Skor Penilaian Aspek Media oleh Ahli Media

Data yang diperoleh dari alpha test (ahli materi dan ahli media) menyatakan bahwa produk multimedia pembelajaran dinyatakan sangat bagus dan layak untuk diuji cobakan dengan revisi. Setelah proses revisi selesai, maka produk multimedia pembelajaran Seni Musik diuji cobakan pada tanggal 15 Mei 2011 pada siswa kelas VIII SMP Muhammadiyah 2 Yogyakarta.

\section{Analisis Data Uji Coba}

Hasil uji coba oleh pengguna diketahui bahwa: pembelajaran bahwa modus skor penilaian pengguna adalah skala 2 sebanyak 7 atau 2,10\% dengan kategori Kurang Baik, skala 3 sebanyak 106 atau 31,8\% dengan kategori Cukup Baik, skala 4 sebanyak 158 atau $47,45 \%$ dengan kategori Baik, dan skala 5 sebanyak 62 atau 18,62\% dengan kategori Sangat Baik. Bila dilihat dari modus maka aspek pembelajaran dikategorikan Baik.

Aspek materi bahwa modus skor penilaian pengguna adalah skala 3 seba- nyak 67 atau 30,18\% dengan kategori Cukup Baik, skala 4 sebanyak 113 atau $50,90 \%$ dengan kategori Baik, dan skala 5 sebanyak 42 atau 18,92\% dengan kategori Sangat Baik. Bila dilihat dari modus maka aspek materi dikategorikan Baik.

Aspek media bahwa modus skor penilaian pengguna adalah skala 3 sebanyak 49 atau 14,71\% dengan kategori $\mathrm{Cu}$ kup Baik, skala 4 sebanyak 123 atau 36,94\% dengan kategori Baik, dan skala 5 sebanyak 161 atau 48,35\% dengan kategori Sangat Baik. Bila dilihat dari modus maka aspek media dikategorikan Sangat Baik. Berdasarkan hasil analisis data yang diperoleh maka produk multimedia pembelajaran Seni Musik dikatakan layak sebagai sumber belajar.

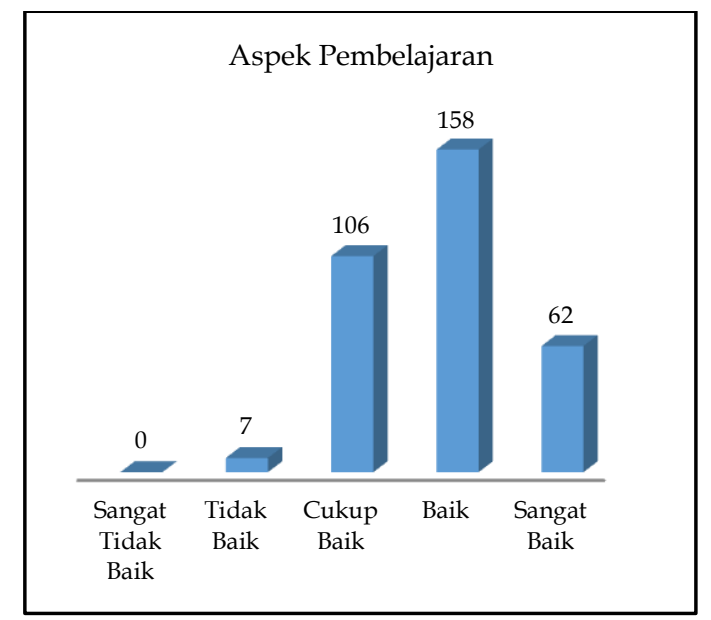

Gambar 5. Perolehan Skor Penilaian Aspek Pembelajaran oleh Pengguna

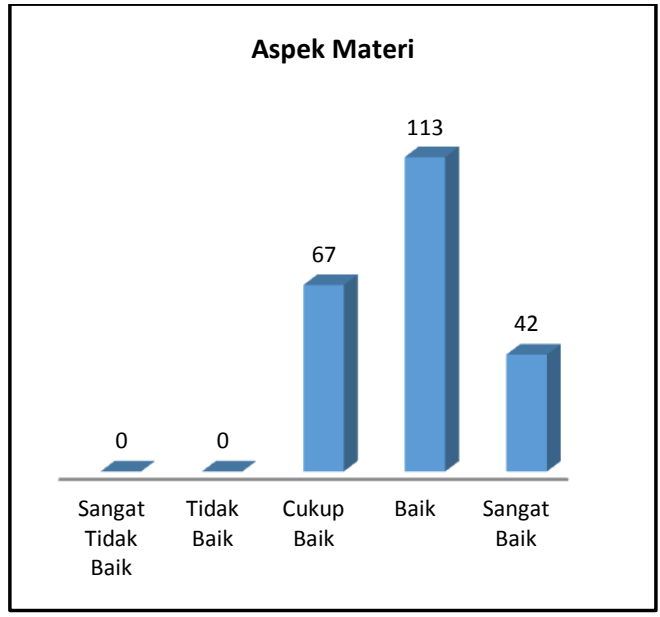

Gambar 6. Perolehan Skor Penilaian Aspek Materi oleh Pengguna 


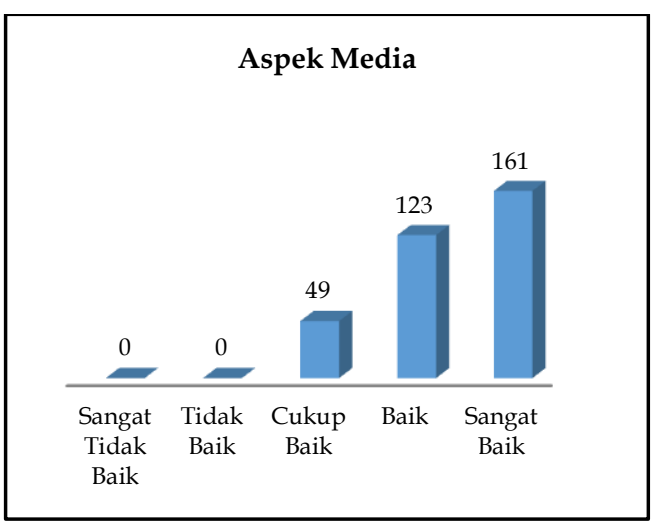

Gambar 6. Perolehan Skor Penilaian Aspek Media oleh Pengguna

Evaluasi yang terdiri dari beberapa tahap yaitu evaluasi dari ahli materi, evaluasi dari ahli media, dan uji coba oleh siswa telah selesai dilakukan. Hal ini berarti pengembangan multimedia pembelajaran Seni Musik ini telah selesai dikembangkan. Revisi terhadap produk yang dikembangkan membawa hasil yang positif terhadap produk multimedia yang dikembangkan. Dengan demikian evaluasi dan revisi sangat diperlukan untuk meningkatkan kualitas produk multimedia pembelajaran yang dikembangkan sehingga menghasilkan media yang berkualitas baik dari aspek pembelajaran, materi maupun media.

Program multimedia pembelajaran didesain dengan memberikan kemudahan dan flexibilitas dalam mengontrol urutan materi. Berdasarkan komentar validator (ahli materi dan ahli media), serta komentar siswa dapat disimpulkan bahwa dengan menggunakan produk multimedia pembelajaran yang dikembangkan, siswa menjadi lebih senang, tidak merasa malu apabila belum menguasai materi, bisa mengulang bagian yang belum dimengerti tanpa merasa rendah diri. Selain itu tampilan produk menarik baik dari segi desain tampilan, materi, dan kebebasan untuk belajar.

Dengan menggunakan aspek-aspek di atas, maka pengembangan multimedia pembelajaran Seni Musik memiliki beberapa keunggulan. Menjadi multimedia pembelajaran yang menarik dan sesuai dengan gaya belajar siswa. Bentuk materi disajikan dalam bentuk teks (visual) dan animasi, sehingga siswa lebih bebas belajar sesuai dengan gaya belajarnya. Hal ini dibuktikan dari komentar, saran, dan penilaian yang diberikan siswa saat uji coba produk.

Mudah dipelajari isinya, karena produk yang dikembangkan telah melalui tahap desain dan pengembangan multimedia. Tahap tersebut meliputi penulisan standar kompetensi dan kompetensi dasar, memilih dan mengembangkan materi pembelajaran, menentukan strategi dan pengalaman belajar, menetapkan indikator. Selain itu, menyusun flowchart dan storyboard yang digunakan di dalam pengembangan multimedia pembelajaran dengan memanfaatkan program Macromedia Flash 8 sebagai program utama dan didukung program lainnya.

Menjadi bagian dari strategi pembelajaran yang memiliki efisiensi waktu yang telatif tinggi, ditunjukkan dengan relatif cepatnya siswa mempelajari materi dari multimedia pembelajaran dibanding bila dilakukan secara tatap muka di kelas.

\section{Simpulan dan Saran}

Simpulan

Berdasarkan hasil analisis data dan pembahasan dapat disimpulkan produk yang dihasilkan berupa CD pembelajaran interaktif yang terdiri dari kompetensi, materi (pengertian, fungsi musik, unsurunsur musik, jenis musik, bentuk instrumen serta keunikan musik), evaluasi, dan referensi. CD pembelajaran interaktif dikatakan layak menurut penilaian dari ahli materi, ahli media, dan melalui uji coba lapangan.

Produk multimedia pembelajaran interaktif Seni Musik yang layak dihasilkan melalui empat tahap. Tahap pertama adalah studi pendahuluan. Tahap kedua perencanaan yaitu:1) mendefinisikan bidang/ ruang lingkup, 2) membuat dokumen perencanaan, 3) menganalisis materi, menganalisis teknologi, menganalisis media. Tahap ketiga desain yaitu 1) mengembangkan ide-ide, 2) menentukan materi pokok, 
3) menuliskan standar kompetensi, kompetensi dasar, 4) menetapkan evaluasi/penilaian, serta membuat flowchart dan storyboard. Tahap keempat pengembanga, yaitu: 1) menyiapkan teks, 2) membuat soal-soal, 3) mengumpulkan foto dan animasi, 4) menyusun dan membuat program, 5) melakukan uji alpha (memvalidasi produk) oleh ahli materi dan ahli media, melakukan uji beta, melakukan revisi akhir, dan 6) melakukan evaluasi sumatif.

Saran

Program multimedia pembelajaran interaktif untuk materi Musik Nusantara ini sesuai dengan prinsip-prinsip desain pembelajaran dan sesuai dengan silabus Seni Musik, serta sudah melalui proses validasi baik oleh ahli materi dan ahli media, serta siswa. Oleh karena itu, pendidik khususnya guru diharapkan dapat menggunakan produk ini sebagai sumber belajar dalam pembelajaran seni musik, sehingga memudahkan dalam mencapai tujuan dan penguasaan materi pembelajaran yang tinggi.

Guna mengatasi kejenuhan dan kemalasan yang dialami siswa, guru dapat menyiapkan sumber belajar yang memiliki daya tarik dengan pemanfaatan teknologi komputer. Selain itu, multimedia pembelajaran interaktif ini jika dimanfaatkan dengan baik akan dapat meningkatkan hasil belajar siswa baik dari aspek kognitif maupun afektifnya. Produk yang dikembangkan ini masih terbatas pada program tutorial, pengembangan produk lebih lanjut tentang CD pembelajaran interaktif dapat dilakukan dengan mengembangkan software pembelajaran dengan program lain, misalnya simulasi, drill $\mathcal{E}$ practice, authoware.

\section{Daftar Pustaka}

Alessy, S.M. \& Trollip S.R. (2001). Multimedia for learning, methods and development. Boston: Allyn and Bacon-A Pearson Education Company.

Ariasdi. (2008). Panduan pengembangan multimedia pembelajaran, diambil tanggal 24 Maret 2010 dari http:// ariasdimultimedia , wordpress.com

Borg, Walter. R. \& Gall, M., D. (1983). Educational research: An introduction (4 $4^{\text {th }}$ ed.). New York \& London: Logman.

Chosky, Lois. (2004). The kodaly context: creating an environment for musical learning. USA: Prentice-Hall, Inc.

Chicago Centre School of Music. Pivate lesson for children. Diambil pada tanggal 22 Februari 2012,dari http: $\mathrm{L} /$ centreschoolofmusic.com/Privat e-Lesson-for-children.php.

Latuheru, J. D. (1988). Media pembelajaran dalam proses belajar-mengajar masa kini. Jakarta: Departemen Pendidikan dan Kebudayaan.

Lee, W.W., \& Owens, D.L. (2004). Multimedia based instructional design (2th ed.). San Francisco: Pfeiffer.

Mogey, N. (1998). Evaluation cookbook. Learning Technology Dissemination Initiativ Edinburgh: Institute for Computer Based Learning HeriotWatt University.

Nana Sudjana \& Ahmad Rivai. (2007). Teknologi pengajaran. Bandung: Sinar Baru Algensindo.

Newby, T. J. et al. (2000). Instructional technology for teaching and learning. New Jersey: Prentice-Hall Inc.

Phillips, R. (1997). The developer's handbook to interactive multimedia: A practical guide for educational applications. London: Kogan Page.

Schweir, R. A., \& Misanchuk, E. R. (1993). Interactive multimedia instructional. New Jersey: Englewood Cliffs.

Smaldino, S.E., Russel, J. D. , Molenda, M., et.al. (2005). Instructional technology and media for learning. (8 edition). New Jersey: Pearson Merrill Prentice Hall.

Yusufhadi Miarso, (2007). Menyemai benih teknologi pendidikan, Jakarta: Kencana. 